\section{Home thoughts from} abroad

\section{London}

A PETITION demanding increased government investment in science, and signed by more than 1,600 British 'brain drain' scientists working abroad, was presented yesterday ( 7 February) to Prime Minister Margaret Thatcher. The petition is the work of British Scientists Abroad (BSA), an academic pressure group set up last year by young British scientists working in California. More than half the signatories have faculty-level positions; 24 are fellows of the Royal Society and over $\mathbf{1 0 0}$ are heads of departments.

Poor career prospects, inadequate research equipment and the abolition of tenure are driving British scientists abroad, according to the BSA, which says that as a proportion of Gross Domestic Product,

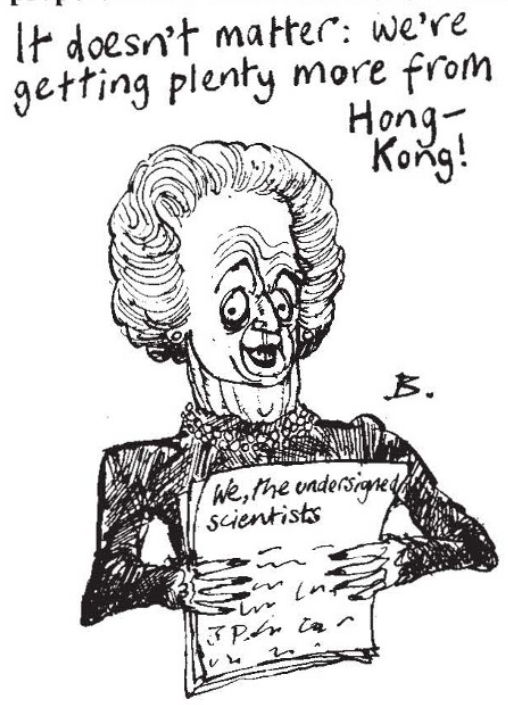

science spending in the United Kingdom is less than in comparable countries such as France and West Germany.

Matthew Freeman, a postdoctoral molecular biologist at Berkeley, California, who helped to organize the petition, says that interest was spurred by a letter from science minister Robert Jackson to the Committee of Vice-Chancellors and Principals (CVCP) in July 1989. Jackson dismissed the British brain-drain scare as a rumour, and challenged the CVCP to come up with hard evidence.

CVCP and the lecturers' union, the Association of University Teachers, have since commissioned a study into recruitment and retention of academic staff.

Poor academic salaries in Britain have contributed to the brain drain, according to Michael Duff, professor of physics at Texas A\&M University since 1988 , who flew to London with a number of other scientists to present the petition. "Competent British academics can easily triple or quadruple their salaries by moving to the United States", he says, and US universities view Britain as a "happy hunting ground" for recruitment.

\title{
Rescheduling reconsidered
}

\section{Washington}

REACTING to criticism from its European partners, the US National Aeronautics and Space Administration (NASA) has begun a new and comprehensive review of its construction schedule for Space Station Freedom. Among the changes now being considered are launching Columbus, the $\$ 4,500$-million experimental module from the European Space Agency (ESA), nearly a year earlier than planned, increasing the size of the space station's solar panels to provide more electrical power and including a Canadian robotic arm earlier in the construction process.

European, Japanese and Canadian space officials have been unhappy with NASA in recent months for making significant changes in the project's schedule without consulting them. Last autumn, NASA 'rephased' the space station after Congress cut nearly $\$ 400$ million from the project's 1990 budget. The foreign partners complained that in the rephased plan most of the international components of the space station were delayed, but most of the US components remained on schedule. In congressional testimony last week, officials from ESA and the Japanese National Space Development Agency (NASDA) said they found out about the NASA schedule review - known as the 'Langley Exercise' - only after it was under way, too late to change its outcome.

ESA director-general Reimar Lüst told the House of Representatives Committee on Science, Space, and Technology that he and other ESA officials met with NASA administrator Richard Truly late last year to register their unhappiness with the Langley Exercise. The unilateral change of schedule "departed radically from both the letter and the spirit" of the memorandum of understanding between the partners, he said. ESA officials told Truly at the time that their financial support for the new plan would not be assured until European concerns had been addressed.

Last week NASA officials sent ESA and NASDA the initial results of a 'complete systems engineering study' they had ordered to find rescheduling options that the international partners might find more acceptable.

The principal change would be to launch the Columbus module in the third quarter of 1997, instead of in June 1998 as the Langley review had recommended. Lüst told the House committee that advancing the launch date by nearly a year could save ESA between $\$ 200$ and $\$ 300$ million. But in a letter to ESA, NASA warned that bringing Columbus up earlier would leave the rest of the space station with only enough power to "stay aiive" until the full solar panel array was installed. "Signifi- cant utilization" by the United States, NASA said, would be delayed by at least eight months, something the US scientific community might find "unacceptable". Another review later this month will consider the possibility of installing larger solar panels on the space station, an upgrade that could give users $6 \mathrm{~kW}(20$ per cent) more power and perhaps ease concern both at home and abroad. But NASA warns that the enlargement is likely to be expensive, and could increase atmospheric drag enough to affect the station's orbit adversely.

NASA is also considering the practicality of bringing a Canadian robotic arm earlier in the construction sequence. It is currently scheduled for the fourth shuttle flight, Canadian officials say that their country's participation in the most visible part of the construction is politically important in securing support at home.

Officials from the partner nations reacted favourably last week to NASA's efforts to find a mutually agreeable compromise. "The new options give an indication that NASA is willing to take our concerns into account, which is very welcome. Up to now we have been brushed off", says Derek Deil, head of ESA's Columbus liaison office.

G. Christopher Anderson

PALAEOPHILATELY

\section{'Dinosaur' birthday to be celebrated}

\section{London}

THE 150th anniversary of the invention of the term 'dinosaur' will be officially marked in 1991 by a commemorative set of dinosaur stamps, the UK Post Office announced this week. The word was coined at the $\mathbf{1 8 4 1}$ meeting of the British Association for the Advancement of Science (BAAS) in Plymouth, where the anatomist Sir Richard Owen described the flesheating reptile Megalosaurus, the herbivorous Iguanodon and the armoured Hylaeosaurus. The BAAS is due to hold its 1991 meeting in Plymouth, and Owen's etymological invention will be part of that year's celebrations.

Palaeontologist Beverly Halstead of Imperial College, London, will be president of the geology section of the BAAS in 1991, and has been campaigning for the special stamp issue. Part of the appeal will be that the first dinosaurs to be described were found in the British Isles.

The dinosaurs that will be depicted have not yet been chosen by the Post Office, but spokesman Barry Robinson confirmed that there was a "firm intention" to issue them. Suitable candidates would include the species mentioned above. Henry Gee 